Vol.3, No. 3, September 2021, pp. 119-129, doi.org:10.52567/pjsr.v3i3.232

www.pjsr.com.pk

\title{
RELATIONSHIP BETWEEN CORPORATE GOVERNANCE AND CORPORATE SUSTAINABILITY
}

\author{
Imran Rafique \\ $\mathrm{PhD}$ Scholar, Centre for South Asian Studies, \\ University of the Punjab, Lahore. \\ imranrafique1931@gmail.com
}

\begin{abstract}
The purpose of this article is to demonstrate that corporate governance is essential to the continued functioning of any company, and much attention has been given to its governance processes. In the same way, sustainability is essential to every company's continued functioning and is perhaps the current trendy idea. Whilst it is obvious what corporate governance usually means, the meaning of sustainability is much less clear, and the article revealed how corporate governance and corporate sustainability interact. A cross-sectional design was followed and the data was gathered from 160 company respondents. The findings of the correlation study indicate an important direct corporate governance and corporate sustainability connection among companies. This research may also be used to detect the effects of corporate governance on company sustainability performance and growth.
\end{abstract}

Keywords: Corporate Governance, Corporate Sustainability, Organizational sustainability, Corporate Authority, Governance

\section{INTRODUCTION}

Corporate governance specifies the framework within which corporations are managed and controlled i.e., corporate objectives and performance monitoring against these goals. Good corporate governance seeks to give board management with incentives to achieve the goals which the firm and its shareholders are interested in (Aras \& Crowther, 2008). This framework includes structural and components of behavior; structural components include the separation of chairman and chief executive officers, and the number of independent board directors; the behavioral components include attendance of directors at board meetings, disclosure of salary and compensation policies of directors. Moreover, the questions of board diversity and the ethical code of a firm are also taken into account while measuring the efficacy of decision-making by a corporation (Aggarwal, 2013; Bae, Masud, Kaium \& Kim, 2018). Although, they are not conventional, they are seen as indications of autonomous and responsible decision-making. Corporate governance specifies a range of connections between the management, board, shareholders and other shareholders of a firm. This is the method through which managers and auditors handle their duties towards shareholders and broader companies. It can give shareholders more confidence in a fair return of their investments. It can assure stakeholders of the company's responsible management of its impact on the environment and the society (Maier, 2005). A wider understanding of corporate governance is gaining grounds in connection with the notion of the stakeholder society. A company has many different stakeholders: employees, clients, suppliers and neighbors, the wellbeing of which must be considered. Corporate management would therefore refer to designing structures to enable managers to internalize the welfare of stakeholders in the company (Klettner, Clarke, \& Boersma, 2014).

Corporate social responsibility refers to a system of interactions between the management, executive board, shareholders and other stakeholders of a business. This is how managers and auditors fulfil their responsibilities towards shareholders and the broader business community, which may instill more confidence in stockholders regarding reasonable return of their investments. It can reassure stakeholders about the company's commitment to responsible management of its effect on the environment and on the communication (Maier, 2005). Increasingly in recent years, an expanded view of corporate governance has gained attraction in conjunction with the concept of the stakeholder society (Klettner et al., 2014). A business has many distinct stakeholders, including workers, customers, 
suppliers, and neighbors, all of whom must be taken into consideration when making decisions about the company's future. As a result, corporate management would refer to the process of creating organizational structures that allow managers to internalize the welfare of all stakeholders in the business. Corporate governance processes are economic and juridical structures which, maybe for the better, can be changed via the political system. According to the evolutionary economic change theory (Alchian, 1950; Stigler \& Economics, 1958), corporate governance would be taken into account in the course of competition. It is the concept of "sustainable development" that is founded on the concept of corporate sustainability.

The United Nations World Environmental and Social Commission coined the phrase "environmental stewardship" in 1987. In order to achieve sustainable development, policies must be implemented that "satisfy the needs of current generations without compromising the needs of future generations"(Pintea, 2015). To address this vacuum of knowledge, we seek to help in expanding the literature by examining the connections between corporate governance and sustainable and financial success in Australia. Australians have been chosen as a case study because the country is regarded as one of the world's innovators in sustainable development, and indeed the Australian government has shown an increasing interest in long-term corporate sustainability. This nation has a long and illustrious history of administration and reporting (Higgins, Milne, \& Van Gramberg, 2015). There are several words to characterize the social and environmental activities of corporations. The most popular corporate social responsibilities (CSR) are the ESG, shared value, threefold bottom line and environmental impact management. Companies may progressively move towards sustainability, steadily increase and extend their activities. Companies often start by ordering their own homes while examining decision making, operations, cultures and other fields inside. They may continue to work with suppliers and other firms to assist organizations learning and share best practices. Eventually, corporations, from community stakeholders to NGOs, need to connect with society.

\section{PROBLEM STATEMENT}

A substantial rise in the desire to achieve sustainable development objectives has occurred in recent years, particularly in the developing countries (Ali \& Atan, 2013). The agenda for sustainable development has been a major source of concern for a variety of governmental and non-governmental groups. Without including the idea of "sustainable," no corporate strategy would be considered complete (Cancela, Neves, Rodrigues \& Dias, 2020). The notion of "sustainability" has also been progressively converted from a macro-environmental problem to a mainstream corporate practice as a result of increasing public awareness and expectations for company conduct. The fundamental question is how to close the gap that now exists between the link among both corporate governance and corporate sustainability, and that is a significant problem in itself (Lin-Hi \& Blumberg, 2011).

\section{RESEARCH OBJECTIVES}

On the topic of corporate governance and corporate sustainability, this study is focused on investigating these topics further. The study is primarily concerned with the investigation of the possibility of longterm growth in companies that are influenced by the corporate governance, managed by governments. Firms and organizational developmental process are affected by the corporate governance which is to be investigated in the present study (W. Lu, 2016). This research would focus on the following objective statement:

- To examine the connection between corporate governance and corporate sustainability.

\section{RESEARCH SIGNIFICANCE}

As a consequence, much attention has been paid to the procedures of corporate governance in general, which is the purpose of this article. Corporate governance is essential to the ongoing operation of any business, as shown in this article. In a similar vein, sustainability is critical to the long-term functioning of any company, and it is perhaps the most popular idea in the business world right now. The term "corporate governance" is well understood in general; however, the term "sustainable" is less understood, and the article begins by looking at this idea. 


\section{LITERATURE REVIEW}

\section{Corporate Governance}

Vives (2000) researched on corporate governance, which is a thriving area of study and a public debate at the moment. Considering the recent expansion of concepts and institutional investments in "shareholder value," the establishment of best practices for corporate boards of directors, and the ongoing debate over whether parts of the market or banking-oriented structures are superior for economic performance. In order for industrialized countries, developing markets, and transitional economies to go forward, the conclusion of this argument must be reached (Lu, 2016). Among the topics covered in this volume are: the state of competition, the philosophy and history of corporate governance, the effectiveness of negative systems on operations and success, venture capital driven policymaking in Silicon Valley, human capital and regulatory frameworks in the new enterprise, and the social resources and regulatory frameworks in the new enterprise.

One of the major problems for company managers, auditors \& auditors, investment managers and government officials is corporate governance. Often the primary aim of a business is to go global while staying sustainable in order to acquire competitive strength. But the most essential issue is what is going to be the path of a company to become global, and what is needed to achieve global competitive strength. There are many possible solutions to this topic, and a business has a number of ways to do this.

Corporate governance has probably received a lot of attention since the mid-1980s. AngloAmerican good governance standards supplied the early impetus. Stimulated by fund managers, other developed and also in developing market nations, a version of these rules was created or modified for their own businesses. Since significant and well-publicized corporate failures and scandals, it is certain that investor confidence has risen which becomes a much more critical problem for the whole financial system. Investors want companies to adhere to rigorous corporate governance rules in order to maximize the returns on investments while keeping the costs of their agency to a minimum. Investors are most often willing to pay extra for businesses with excellent governance standards. Similarly, the corporate management report of a business is one of the primary instruments for investment choices. For these purposes, businesses cannot disregard the pressure on shareholders, prospective investors and as well as other market players to achieve excellent governance (Lu, 2020; Lu, 2016).

At the same time, banking creditworthiness measurement laws need new criteria for the credit assessment of a business. New international techniques for assessing bank adequacy require the credit assessment criteria to deal in detail with operational risks, which among alia, includes the principles of corporate governance. Corporate governance is one of the most significant indicators for risk measurement in this regard. Another problem is the trustworthiness and danger of the company. If the company requires a good rating, attention should also be paid to company governance standards. Credit rating firms analyze company management practices and other corporate factors, even though corporate governance requirements have always been necessary for obtaining good credit ratings for large and publicly traded companies as they are becoming more important for investors, potential investors, creditors, and the government as a whole. Because of all these reasons, the agenda of policy-makers, financial institutions, investors, businesses and academics has significant importance in corporate governance. The relationship between corporate governance with its overall performance is still being debated, which is one of the most significant indicators. A large number of studies have looked at the relationship between corporate governance and literary achievement. The majority of studies had mixed results, with no clear connection between them. Based on these findings, corporate management seems to be important for the performance, selling price and credibility of a business to render all companies follow corporate governance rules. However, corporate governance seems to be the sole way for businesses to accomplish corporate objectives and plans. Companies must enhance their strategies and effectively implementing governance principles by examining the policies and practices of their corporate governance (Lu, 2020)

\section{Corporate Governance}

Corporate governance relates to how and for what purpose businesses are governed. It defines who is empowered and responsible in decision making process. In essence, it is a toolbox that allows managers 
and executives to tackle the difficulties of operating a business more efficiently. Corporate governance guarantees that companies have adequate decision making policies and regulations to ensure that all stakeholders are interested. Corporate governance comprises procedures by which the goals of a business are established and implemented in the social, governmental and commercial environment. It is about methods and processes to ensure that a business is managed in such a manner that it accomplishes its goals and ensures that stakeholders confidence in their firm is properly established.

The Institute believes that a good governance is essential because it offers the framework to enhance the quality of corporate decision-makers. Good quality and appropriate ethics create sustainable companies and allows them to produce more effective long-term value.

\section{Corporate Governance and Development}

Claessens (2006) established that good corporate governance usually provides dividends to businesses, markets and governments. It is linked to lower capital, more equality, more efficiency and better treatment of all stakeholders, but in this context, the causal direction is not always evident. In recent years, legal and financial literature has shown the critical role played by legal and contractual enforcement authorities throughout the globe, particularly in the area of corporate governance. Firm-level data enabled the researchers to establish a link between the corporate governance framework of different countries with performance measures like as earnings appraisals, capital costs, and approach to exterior financing on the other crosswise. Companies and countries should be able to reform more freely in light of the advantages of good corporate governance due to resistance from long-established owners and managers, as well as governmental and profitable factors at the market and national levels.

\section{International Corporate Governance}

Denis \& McConnell (2003) analyzed two generations of study on corporate governance systems across the world, focusing on non-US countries. The first wave of foreign corporate governance research is modelled on US research. These studies analyze the makeup and equity ownership of individual governance systems in various nations. The second generation of international corporate governance research takes account of the probable effects of different legal systems on company governance structure and efficiency, and compares systems across nations.

\section{Importance of Corporate Sustainability Business}

Lo and Sheu (2007) gave a new approach that combines sustainability with finance, garnering worldwide attention. The corporate sustainability impact on market value is studied in this research by big US nonfinancial businesses from 1999 to 2002. Compelling Tobin's q as a proxy for firm value, the relationship between corporate sustainability and its market value has been considerably favorable. We also see a substantial interaction effect on firm value between corporate sustainability and sales growth. In addition, there is an evidence that a company's sustainability increases its worth. This suggests that firms with outstanding sustainable growth plans are more likely to be rewarded in the financial markets by investors with a higher value.

\section{Corporate Sustainability and Performance}

Eccles, Ioannou \& Serafeim (2014) investigated and conducted examination on the effect of business sustainability on organizational performance and long-term viability. In accordance with findings from a dataset consisting of 180 U.S. companies, companies that willingly adopted effective development by 1993 when contrasted with a significant number of firms who had implemented any of these rules, they had unique organizational processes and referred to as low-sustainability companies which had different organizational processes before 2009. Companies that volunteered to implement effective practices had separate organizational procedures before 2009 till 1993. In comparison to managers of small-scale enterprises, managers from high-sustainability enterprises are so much more likely to be held personally responsible for sustainability, and higher management pay motivations are far more likely to impact sustainability metrics. Those companies that have achieved a high degree of sustainability are more likely to have stakeholder engagement systems in place, to be more long-term oriented, and therefore have more 
non-financial information tracking and sharing in their operations. To summaries, businesses with a high level of sustainability have a much higher long-term success record than their competitors, both in terms of market price and financial performance.

\section{MATERIAL AND METHODS}

A quantitative cross-sectional survey was conducted to collect the primary data consisting on the defined variables. The corporate data was used to conduct this quantitative investigation. Data was collected from 140 survey participants, and questionnaire survey was employed as a data collection tool. Analysis technique is a mean of helping researchers to address research issues. The research approach usually explains how the research is systematically carried out by the researcher.

This research employed descriptive research design. Descriptive analysis design is used to define new information about persons, events, behaviors, conditions, or the occurrence of such events or circumstances (Gliner, Morgan, Harmon \& Psychiatry, 2000). Descriptive analysis is sometimes referred

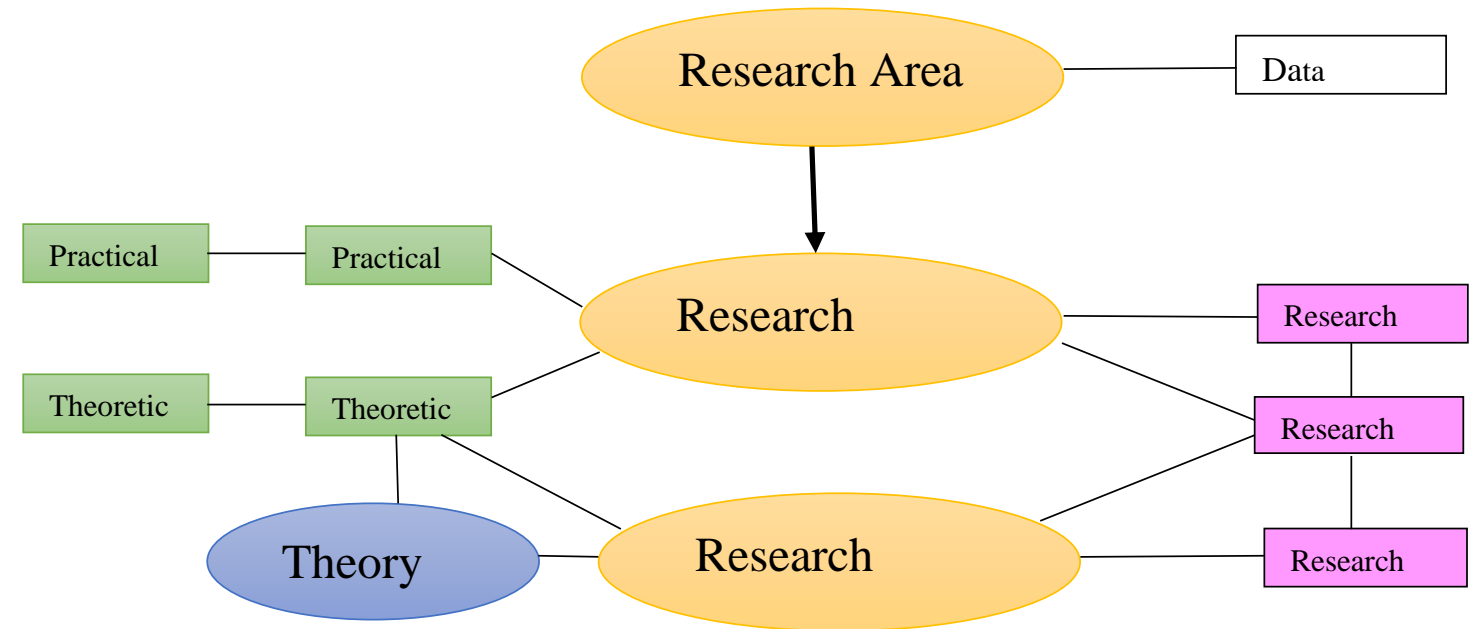

to as descriptive research, and may define the results and features of any study.

\section{Deductive approach}

While using the deductive approach, the assumption is made that the body language hypothesis has been accepted, and the hypothesis is refined into more precise, testable hypotheses that are then examined.

Fig 1: Study Framework

Following the findings of new information, further filtering may be carried out in order to resolve the hypotheses that were previously held. As a result of this procedure, the researcher would be able to check the data and validate the validity of the current study hypothesis at some point. According to their results, when beginning work from a deductive perspective, Saunders, Lewis, \& Irvine (2009) suggested that an appropriate methodology must be used to create an acceptable method rather than starting from scratch.

\section{Research Framework}

For the survey execution, we have followed the custom design approach (Dillman, 2000). This approach shows that surveys achieved strong answer rates. The first communication is an e-mail until notification. The pre-notice is constructive to inform the respondents that he or she is being asked to contribute by taking part in the inquiry. Sending that pre notice increases the average answer rate by about 5\% (Dillman, 2000). The advance note was sent by the company manager containing information about what the survey is all about and how helpful it will be for the researcher. 


\section{Theoretical Framework}

Structural equation modelling (SEM) is a collection of statistical methods that are used to assess and evaluate the connections between observable and latent variables in a data set. Analysis of linear causal connections between variables, which is similar to but more powerful than regression analysis, is performed while concurrently accounting for measurement error. The aim of this article is to explain how structural equation modelling (SEM) may be used to examine the connection between corporate governance and business sustainability.

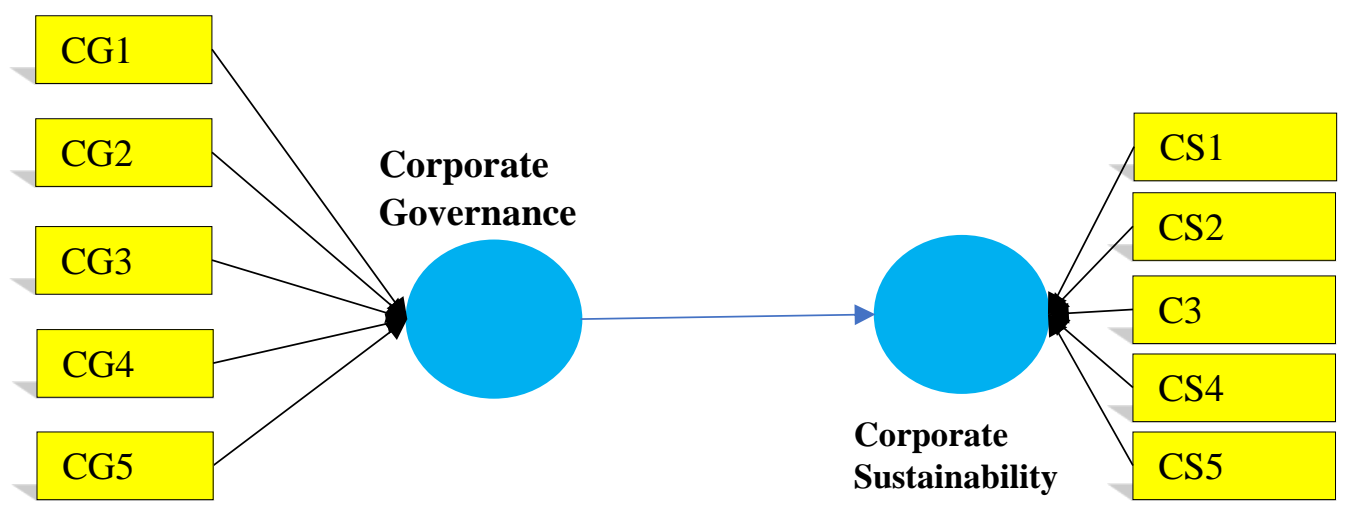

\section{Fig 2: Conceptual Framework}

\section{Hypothesis formation}

H0: There is no significant relationship exists between the corporate governance and corporate sustainability

H1: There is a significant positive relationship exists between the corporate governance and corporate sustainability.

\section{RESULTS}

Demographics of the respondents are given in the table 1. Table shows the percentage distribution of the respondents by gender, marital status, age groups, qualification and experience. Male and female respondents are $71 \%$ and $29 \%$ respectively, while $56.1 \%$ and $43.9 \%$ of the respondents are single, which illustrates that most of the respondents are not married. Rest of the categorical distribution can be seen in the table.

Table 1. Percentage Distribution

\begin{tabular}{|c|c|c|}
\hline Table N \% & & \\
\hline \multirow[t]{2}{*}{ Gender of the respondents } & Male & $71.0 \%$ \\
\hline & Female & $29.0 \%$ \\
\hline \multirow{2}{*}{ Marital status of the respondents } & Single & $56.1 \%$ \\
\hline & Married & $43.9 \%$ \\
\hline \multirow[t]{4}{*}{ Age of the respondents } & $18-25$ years & $29.8 \%$ \\
\hline & $25-35$ years & $53.4 \%$ \\
\hline & $35-50$ years & $16.8 \%$ \\
\hline & Above 50 & $0.0 \%$ \\
\hline \multirow{3}{*}{ Qualification of the respondents } & Graduation & $40.2 \%$ \\
\hline & Master & $39.9 \%$ \\
\hline & $\mathrm{PhD}$ & $1.5 \%$ \\
\hline
\end{tabular}




\begin{tabular}{|c|c|c|}
\hline & Other & $18.4 \%$ \\
\hline \multirow[t]{4}{*}{ Experience of the respondents } & Less than 1 year & $4.2 \%$ \\
\hline & $1-5$ years & $59.6 \%$ \\
\hline & $6-10$ years & $31.4 \%$ \\
\hline & Above 10 years & $4.9 \%$ \\
\hline
\end{tabular}

\section{Descriptive statistics}

Descriptive statistics for corporate governance is given below showing a minimum score of 2 and highest score of 5 , while mean values can be seen between the decimals of 4 .

Table 2. Descriptive Statistics of Corporate Governance

\begin{tabular}{|c|c|c|c|c|c|c|}
\hline & & $\mathbf{N}$ & Minimum & Maximum & Mean & Std. Deviation \\
\hline \multirow{2}{*}{ GC1 } & & 1 & 1.0 & 5.00 & 2.2785 & 1.15736 \\
\hline & 60 & & 0 & & & \\
\hline \multirow[t]{2}{*}{ GC2 } & & 1 & 1.0 & 5.00 & 2.5297 & 1.18197 \\
\hline & 60 & & 0 & & & \\
\hline \multirow[t]{2}{*}{ GC3 } & & 1 & 1.0 & 5.00 & 2.5799 & 1.29811 \\
\hline & 60 & & 0 & & & \\
\hline \multirow[t]{2}{*}{ GC4 } & & 1 & 1.0 & 5.00 & 2.4932 & 1.20538 \\
\hline & 60 & & 0 & & & \\
\hline \multirow[t]{2}{*}{ GC5 } & & 1 & 1.0 & 5.00 & 2.4795 & 1.15865 \\
\hline & 60 & & 0 & & & \\
\hline Valid N & 60 & 1 & & & & \\
\hline
\end{tabular}

While the corporate sustainability descriptive analysis is given below in the Table 3, which shows the mean values in decimal of 4 as can be seen in the table below.

Table 3. Descriptive Statistics Corporate Sustainability

\begin{tabular}{lllllr}
\hline & N & Minimum & Maximum & Mean & Std. Deviation \\
\hline GC1 & 160 & 1.00 & 5.00 & 4.1785 & 1.32216 \\
\hline GC2 & 160 & 1.00 & 5.00 & 4.3297 & 1.12397 \\
\hline GC3 & 160 & 1.00 & 5.00 & 4.1390 & 1.46521 \\
\hline GC4 & 160 & 1.00 & 5.00 & 4.4332 & 1.48248 \\
\hline GC5 & 160 & 1.00 & 5.00 & 4.4190 & 1.39915 \\
\hline Valid N & 160 & & & & \\
\hline
\end{tabular}

\section{Reliability and Validity analysis}

Reliability and validity of the scale data is measured using Cronbach's alpha and KMO factor analysis of the data. The Cronbach's alpha values 0.77 , which suggests that the data is reliable to make further analysis such as correlations, and can either be used to investigate regression model. Likewise, the KMO factor analysis shows a significant value of 0.87 which is suggesting that the data is normal and valid for further analysis.

\begin{tabular}{|l|l|}
\hline \multicolumn{2}{|c|}{ Reliability Statistics } \\
\hline Cronbach's Alpha & N of Items \\
\hline
\end{tabular}


Rafique

\begin{tabular}{|c|c|}
\hline .767 & 10 \\
& \\
\hline
\end{tabular}

Factor Analysis

Factor analysis of the components is given below, which suggests surprisingly better loadings to support the variables.
Table 6. Reliability and Factor Analysis

\begin{tabular}{|l|l|l|}
\hline \multicolumn{3}{|c|}{ KMO and Bartlett's Test } \\
\hline $\begin{array}{l}\text { Kaiser-Meyer-Olkin Measure of Sampling } \\
\text { Adequacy. }\end{array}$ & 831 \\
\hline $\begin{array}{l}\text { Bartlett's Test of } \\
\text { Sphericity }\end{array}$ & Approx. Chi-Square & 191.410 \\
\cline { 2 - 3 } & df & 27 \\
\cline { 2 - 3 } & Sig. & 003 \\
\hline
\end{tabular}

\begin{tabular}{|c|c|c|}
\hline \multicolumn{3}{|c|}{ Table 7 Factor Analysis } \\
\hline & Initial & Extraction \\
\hline GC1 & 1.000 & .816 \\
\hline GC2 & 1.000 & .753 \\
\hline GC3 & 1.000 & .734 \\
\hline GC4 & 1.000 & .778 \\
\hline GC5 & 1.000 & .906 \\
\hline CS1 & 1.000 & .820 \\
\hline CS2 & 1.000 & .731 \\
\hline CS3 & 1.000 & .715 \\
\hline CS4 & 1.000 & .781 \\
\hline CS5 & 1.000 & .918 \\
\hline
\end{tabular}

\section{Correlation and regression analysis}

Pearson correlation analysis is used to identify the relationship between both the variables, which shows a significant $(\mathrm{p}=0.00)$ positive relationship, suggest a rise in the corporate sustainability with the good corporate governance. The study has indicated clear direct relation between the corporate governance and corporate sustainability, which means if the governance corporation makes good improvements, it will give rise to higher corporate sustainable developments. Correlation results are significant at $\mathrm{p}=0.000$, which can be seen in the Table 8 .

$\begin{array}{ll}\text { Corporate } & \text { Corporate } \\ \text { Governance } & \text { Sustainability }\end{array}$

$\begin{array}{llll}\text { Corporate Governance } & \text { Pearson Correlation } & 1 & .921^{* *}\end{array}$

\begin{tabular}{llll} 
& \multicolumn{2}{c}{ Sig. (2-tailed) } & .000 \\
\cline { 2 - 4 } Corporate & $\mathrm{N}$ & 159 & 159 \\
\hline \multirow{2}{*}{$\begin{array}{c}\text { Sustainability } \\
\end{array}$} & Pearson Correlation & $.921^{* *}$ & 1 \\
& & .000 & \\
\cline { 2 - 3 } & Sig. (2-tailed) & 159 & 159
\end{tabular}




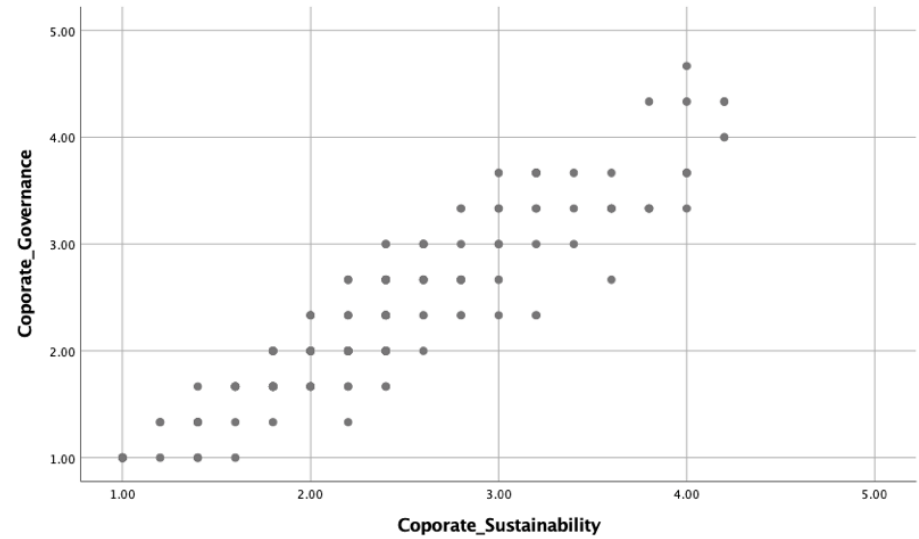

Figure 3: Scatterplots of the corporate governance, and corporate sustainability

The findings of the study of correlation and dispersion indicate a direct connection between corporate governance and business sustainability. The evidences from the primary data and the analysis of the results demonstrated that the objectives and hypothesis of the study are accepted as shown in the results.

\section{DISCUSSION}

Whenever society confronts a new issue or danger, it introduces a new legislative procedure to safeguard its interest against a future repetition (Romano, 2004). We have recently witnessed a large variety of business behavior issues which have probably contributed to corporate social responsibilities including recognizing the interests of all stakeholders in an organization, which many people have investigated. Thus, with their increasing responsibilities and accountability to respective stakeholders, companies believed that a code of corporate governance should be developed to direct them to develop adequate stakeholder relationships (Crowther \& Gular, 2008).

There has been a lot of worry across the globe regarding weak points in corporate governance systems: Britain, Australia, most other English-speaking nations in Anglo-Saxon, English and many other countries share a similar governance structure. In reversal, Germany is the best example where the difference between ownership is considerably smaller than in the USA, while in other ways, Japan's corporate governance system is different from Germany, as well as the USA and others. In India, the system of corporate governance may be described as a transitory system with the main actors (especially politicians, bureaucrats and managers) adopting an overly short-sighted perspective of the governance structure (Eccles, Ioannou \& Serafeim, 2014). These global comparisons illustrate different approaches to corporate governance to ensure that managers work for the benefit of their shareholders. This has recently, received significant attention from institutional investors (Jizi, Salama, Dixon, \& Stratling, 2014; Shrivastava \& Addas, 2014).

Good management is essential in all spheres of society whether in the corporate environment or in general society or politics. For example, good governance may increase public trust in the political context. If the assets are too insufficient to fulfil the people's basic expectations, effective governance may assist to promote the well-being of the society. (Kocmanová, Hřebíček, \& Dočekalová, 2011; Sánchez, Sotorrío, \& Díez, 2011).

Business leadership may be viewed as an atmosphere of trust, morality, moral values and trust as a collaborative effort between all parts of the society, including the government, the general public, etc. The organization's activities and their repercussions is a growing concern for corporate governance. Corporate governance is a motto in the globe today(Kocmanová et al., 2011). In recent years, it has acquired enormous significance along with the necessity for new business ethics, economic liberalization and trade and industry deregulations. Another factor that is responsible for the corporate sector's sudden 
exposure to a new corporate governance paradigm is a modern demand for greater corporate responsibility towards its shareholders and customers.

\section{CONCLUSION}

With regard to the hypotheses that we proposed, the type of research we undertook was qualitative and; therefore, not enough to prove or refute these hypotheses. Thus, effective corporate governance cannot be said to address such problems. What can be said; however, is that a company which understands both sustainability and corporate governance can fully address these problems including a more comprehensive knowledge of the connections will lead to improved corporate governance, which means that these assumptions are true.

The second conclusion of this study concerns the degree of transparency by disclosing corporate governance and sustainable development issues while keeping with the nature of the forecast (Eccles et al., 2014). Crowther (2000) attempted to trace an archaeology of corporate reporting, showing that, in the course of time, the amount of data given - first to stock holders, then to potential investors and then to other stakeholders - has increased gradually over the course of the last century as firms have realized the benefit of increasing disclosure. In addition, during the past decade, the quantity of CSR disclosure has quickly grown as companies have recognized the economic advantages of greater openness. It is therefore reasonable - as we do - to argue that the amount of information on the relationship between management and sustainability will also start increasing when they understand the value of increased disclosure in this regard. So we infer that over time, the validity of our theories will become clearer (Peters \& Romi, 2015).

\section{Policy Recommendations}

Depending upon the nature of the study and the analytical results, the study would like to suggest that government authorities should keep the sustainability of corporates in front, as both the variables correlate significantly with each other.

\section{REFERENCES}

Aggarwal, P. (2013). Impact of corporate governance on corporate financial performance. IOSR Journal of Business and Management, 13(3), 01-05.

Ali, M.A.M., \& Atan, R. (2013). The relationship between corporate governance and corporate social responsibility disclosure: a case of high Malaysian sustainability companies and global sustainability companies. Economics and law, 3(1), 39-48.

Aras, G., \& Crowther, D. (2008). Governance and sustainability: An investigation into the relationship between corporate governance and corporate sustainability. Management Decision.

Bae, S.M., Masud, M., Kaium, A., \& Kim, J.D. (2018). A cross-country investigation of corporate governance and corporate sustainability disclosure: A signaling theory perspective. Sustainability, 10(8), 2611.

Cancela, B.L., Neves, M.E.D., Rodrigues, L.L. \& Dias, A.C.G. (2020). The influence of corporate governance on corporate sustainability: new evidence using panel data in the Iberian macroeconomic environment. International Journal of Accounting \& Information Management.

Claessens, S. (2006). Corporate Governance and Development. The World Bank Research Observer, 21(1), 91-122.

Crowther, D., \& Gular, A. (2008). Governance and sustainability: An Investigation into the Relationship between Corporate Governance and Corporate. Management Decision, 46(3), 433-448.

Denis, D.K., McConnell, J.T. (2003). International corporate governance. The Journal of Financial and Quantitative Analysis, 38(1), 1-36.

Eccles, R.G., Ioannou, I., \& Serafeim, G. (2014a). The impact of corporate sustainability on organizational processes and performance. Management Science, 60(11), 2835-2857.

Eccles, R.G., Ioannou, I., \& Serafeim, G.J.M.S. (2014). The impact of corporate sustainability on organizational processes and performance. 60(11), 2835-2857.

Gliner, J.A., Morgan, G.A., Harmon, R. (2000). Single-subject designs. J Am Acad Child Adolesc Psychiatry, 39 (6), 744-6. 
Higgins, C., Milne, M.J., \& Van Gramberg, B. (2015). The uptake of sustainability reporting in Australia. Journal of Business Ethics, 129(2), 445-468.

Jizi, M. I., Salama, A., Dixon, R., \& Stratling, R. (2014). Corporate governance and corporate social responsibility disclosure: Evidence from the US banking sector. Journal of business ethics, 125(4), 601-615.

Klettner, A., Clarke, T., \& Boersma, M. (2014). The governance of corporate sustainability: Empirical insights into the development, leadership and implementation of responsible business strategy. Journal of business ethics, 122(1), 145-165.

Kocmanová, A., Hřebíček, J., \& Dočekalová, M. (2011). Corporate Governance And Sustainability. Economics \& Management, 16.

Lin-Hi, N., \& Blumberg, I. (2011). The relationship between corporate governance, global governance, and sustainable profits: lessons learned from BP. Corporate Governance: The International Journal of Business in Society.

Lo, S. F., \& Sheu, H.J (2007). Is corporate sustainability a value-increasing strategy for business?. Coporate Governance: An international Review, 15(2), 345-358.

Lu, L. W. (2020). The moderating effect of corporate governance on the relationship between corporate sustainability performance and corporate financial performance. International Journal of Disclosure and Governance, 1-14.

Lu, W. (2016). An exploration of the associations among corporate sustainability performance, corporate governance, and corporate financial performance. Reterived from: http://hdl.handle.net/10106/25557

Maier, S. (2005). How global is good corporate governance. Ethical investments Research study. Reterivedfrom:http://www.eiris.org/files/research\%20publications/howglobalisgoodcorpgov05.pd

Peters, G.F., \& Romi, A.M. (2015). The association between sustainability governance characteristics and the assurance of corporate sustainability reports. Auditing: A Journal of Practice \& Theory, 34(1), 163-198.

Pintea, M.O. (2015). The relationship between corporate governance and corporate social responsibility. Review of Economic Studies and Research Virgil Madgearu, 8(1), 91-108.

Sánchez, J.L.F., Sotorrío, L.L., \& Díez, E.B. (2011). The relationship between corporate governance and corporate social behavior: a structural equation model analysis. Corporate Social Responsibility and Environmental Management, 18(2), 91-101.

Shrivastava, P., \& Addas, A. (2014). The impact of corporate governance on sustainability performance. Journal of Sustainable Finance \& Investment, 4(1), 21-37.

Vives, X. (2000). Corporate governance. Corporate Governance: Theoretical and Empirical perspectives. Cambridge University press. 